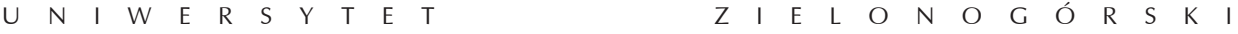

Przegląd Narodowościowy - Review of Nationalities

Jews $\mathrm{nr} 6 / 2016$

\title{
Raul Hilberg, Zagłada Żydów Europejskich, Centrum Badań nad Zagładą Żydów, Warszawa 2014, pp. 1680
}

The book, which for political reasons could not appear in Germany and in Israel for many years, arouses interest among readers before publication in Poland. Our native publishing market waited for more than half a century since its first release in the US for the book of Raul Hilberg Zagłada Żydów europejskich (The Destruction of the European Jews). It is the study of the Holocaust, presented in the form of a description of the process that took place in Europe before and during World War II. The author, who came from a family of Galician Jews, was one of the victims of the Holocaust. To survive, he and his family were forced to emigrate from Europe. He came to the continent again as an American soldier. After the war, he received his promotion to intelligence officer. He analyzed the German documents. He had almost unlimited access to the bureaucratic records relating to "the final solution", which were saved from destruction. After demobilization he studied history, law and political science at Columbia University. The Destruction of the European Jews was the title of his doctoral dissertation. This work was used to write the book, which violated in some way the existing canon of writing about the Shoah. It became a landmark work in the field of Holocaust Studies. Its uniqueness lies in the fact that the author does not focus on the victims but on the process and mechanism of the extermination of the Jews. Victims tend to be just a background for a detailed analysis of the operation of the German administration in the context of the operation of "a machine of destruction". I have the impression that the cold, analytical and precise language, and minimized to the necessary limits empathy is used to highlight in the first place not the assessment of events but the description. The aim of the study was to show, first of all, "how it happened" and not to look for answers to other questions. The described events are not presented from the victims' but the perpetrators' point of view. Hilberg 
claimed that "only the perpetrator had a picture of the whole". He searched for answers to the question "why?" at structures, not ideology. From the very beginning, this method of treatment of the subject has aroused much controversy among other researchers and reviewers. A particular reason for this criticism's was the described activity of Judenrat, which the Germans used as an instrument in the organization of the Holocaust.

The first edition of the book appeared in the early sixties and it was hardly noticed. Another, revised and supplemented book appeared 24 years later. The third edition was published in 2003. All his adult life, Hilberg devoted to research on the Holocaust and replenishing his work with new details and information. For many years, he struggled also with the opponents of this approach to the subject. He died before his monograph was translated into Hebrew and released in Israel in 2012. Polish edition (2014) is the last, and yet the most complete version of this work. It is based on the third edition, which the author had been constantly developing with new content, and collaborating with the Polish translation until his death in 2007.

This monumental Raul Hilberg's opus magnum consists of three volumes. On almost 1,700 pages, he describes meticulously, in a precise manner the functioning of the German structures: the civil service, the military, business and parties, which were harnessed for the work of the totalitarian system. It shows how all the elements of the system, despite the lack of a separate agency for the Jews, cooperated and participated in the process. It should be emphasized that the reference to the Jews in the title does not mean that the work is dedicated just to them. In my opinion, this is more a book about the Germans - the perpetrators of the Holocaust. The book opens with a brief illustrating of the first stage of the anti-Jewish policy, which began from the moment when Christianity became the state religion of Rome in the early fourth century A.D. Over the next centuries, the Jews were subjected to a greater or lesser pressure. According to the researcher, they were "the precedents" that ultimately led to the Holocaust. He described the structure of destruction as a process spread over various stages. He passes much of the information through tables and graphs. We can read about the period when Adolf Hitler came to power, which was the impetus for the administrative apparatus to the anti-Jewish actions. The author argues that just the German authorities gave the pace of the Holocaust while building systemic framework of this project. The officials defined who would be subject to what rules. In subsequent years, when and who would be deported to the death camps. Aryanization of Germany, among others, expropriation, dismissal, special taxes, orders of forced labor and the reduction of wages were only a stage on the road to complete elimination of the Jews. The next phase of the process illustrated in the pages of the book is the concentration of the Jewish community in the territory of the Reich and the Protectorate. 
The evictions, creating ghettos, forced labor, transports, food supply, executions and deaths. All this is described accurately and precisely, like a report of a chartered accountant. This paints a perfect picture of an orderly destruction. The author gives numbers, dates, places and names. He recalls the death squads Einsatzgruppen, subsequent rules and regulations of the Nazi authorities, supplementing them with the reports of high dignitaries.

About the policy of emigration and deportations, we learn from the second volume. The author refers to the plans of expulsion of the Jews to Madagascar, to the Wannsee Conference, as well as territorial structures of railroads. In each rail directorate, there was an operational office with the cell called "office 33", which dealt with passenger trains. Although the Jews were transported in freight cars, the settlement specialists described them as regular passengers, for which the railway received payment for their transfer from the Reich Main Security Office (Reichssicherheitshauptamt). The process of destruction is described not only in terms of functionality, but territorially as well. Geographical expansion of the "final solution" spread from Polish territories, where the largest Jewish diaspora in Europe lived, to other lands subject to German influence.

The last volume of the monograph is about the activity of extermination centers. A complicated mechanism of formation and activities of the concentration camps is illustrated systematically. The author also presents a collaboration of industry with death factories in order to streamline the process of extermination. "A man stepped out of the train in the morning, in the evening his body was burned, and his clothing was packaged to send to Germany. Such an operation required enormous planning". Initially alarming data about the gas chambers, "technical" aspects of the furnaces and chimneys of the crematoria proved to be nothing compared to the apocalyptic descriptions of mass graves. The final pages of the book contain a reflection on the perpetrators and their "psychological problems". We can also read about the phenomenon of an almost complete lack of resistance and helpless attitude towards the victims of the Nazis. The witnesses of the events, the neighbors and the remaining part of the Jewish population characterized a similar attitude. We can find there descriptions of the post-war trials of the Nazis, and how many of them escaped responsibility. The whole is crowned with a calling a lot of controversy chapter on statistics of the Jewish victims.

I think Raul Hilberg's book "The Destruction of the European Jews" is unique. It is a milestone in the study of the Holocaust. Thanks to it, we manage to find the answer to the question: how did it happen? Existing publications about the Shoah mostly revolve around studies designed to answer the question why this happened. They described eyewitness accounts, analyzed the documents in order to understand the 
causes and consequences of genocide. However, these messages were often associated with the possibility of interpretation, their own subjective feelings. Relying on this historical material would be a denial of science. Hilberg's work, through its accuracy, by referring to several independent sources could become a point of reference for subsequent researchers, who should read this book. In my opinion, it can be considered one of the most important scientific studies on the Holocaust.

Krzysztof Łoziński*

* BA in political science, Institute of Political Science, University of Zielona Góra. Mail: biuro@lozinski.pl. 